\title{
切土法面の維持管理
}

\section{Maintenance of cut slope}

\author{
奥園誠之 ${ }^{a) *}$
}

Seishi OKUZONO

\begin{abstract}
When a completed cut slope fails, it not only damages the existing facilities at the bottom of the slope, but also causes other disasters such as loss of human lives. Maintenance measures of a cut slope are of two types: (1) prior reinforcement of the particular slope area that has the potential of failing, and (2) evacuation of people in the neighborhood and closing of roads for the vehicles just before the slope failure.

In this paper, at first the actual slope failure situations and the classifications of cut slope failure (based on the failure form) are introduced. Then, some ideas are proposed that can effectively deal with the slope maintenance measures mentioned in (1) and (2) avobe. The problems and solutions to the present state of affairs of the surveying and inspection technology of cut slopes are also finally addressed.

Key words : cut slope, maintenance, classification of failure form, rainfall, monitoring

\section{和文要旨}

切土のり面の崩壊による災害を防ぐためには，崩壊しそうなのり面を先回りして補強するか，崩壊する直前に通行止めや避難す るかのいずれかである。本小論では道路のり面災害の実態を紹介し, 点検管理, 計測管理, 降雨量管理の考え方について述べたも のである。

キーワード：切土，維持管理，崩壊形態分類，点検管理，計測管理，降雨量管理
\end{abstract}

\section{まえがき}

切土法面は切土した瞬間から，膨張・風化等により地 盤は二次的に強度が低下し，当初安定であったものも， 降雨や融雪等の引金によって崩壊を起こすことがある。

切土法面の崩壊は下部の施設に対して，人命にかかわ る災害を引き起こすことが多い。

安全安心な法面を維持管理するためには, (1)崩壊しそ うな個所を先回りして補強する方法と, (2)崩壊を起こす 直前に通行止めや避難する方法とがある。

本小論では切土法面の災害実態と崩壊形態を紹介し, 前記(1), (2)の目的を達成させるための考え方, 特に点 検・計測技術の問題点とその対策について述べる。

\section{1. 切土法面の災害実態}

切土（きりど）法面（のりめん）とは，自然斜面に対 して地盤を人工的に掘削してできた斜面をいい, 切取(き りとり）法面ともいう。

我が国の切土法面のルーツは不明であり，古くから土 取りをした場所には“法面”があったはずであるが，歴 史上残されているのは約800年前に造られた鎌倉の切通 しであろう。朝日奈・名越し・釈迦堂・亀ヶ谷坂等の有 名な切通しが現存している。これらは軍事道路であり， 切土法面を使った要塞を目的としたもので，のみとつる はしを用いた人力施工である。

切土は自然の地山（地盤）を削る行為であり，地中の

\footnotetext{
* 連絡著者/corresponding author

）九州産業大学工学部都市基盤デザイン工学科

Faculty of Engineering, Kyushu Sangyo University

T 813-8503 福岡市東区松香台2-3-1

2-3-1, Matsukaday, Higashi-ku, Fukuoka, 813-8503, Japan
}

新鮮な岩盤を表にさらすため，自然のバランスを壊すこ とがある。

切土法面の崩壊の原因は，素因と誘因に大別される。 素因は，人間でいえば体質に当たるもので，地盤（以後 地山という）の物性（土質）・構造（地質）・水（地下水） に支配されるものである。誘因は，人間でいえば過酷な 労働や運動, 不摂生に当たる外的条件であり，降雨や地 震，それに無理な設計施工等に支配されるものである。

道路・鉄道・宅地などにおいて切土法面が崩壊すると 人命にかかわる災害となることがある。石 1 個でも直撃 されれば，人災となる可能性が高い。

近年マニュアル（例えば，道路土工指針 ${ }^{1}{ }^{\prime}$ ：日本道路 協会)の普及により，無理な設計施工は少なくなり，個々 の法面の崩壊率は小さくなっているといえる。しかし新

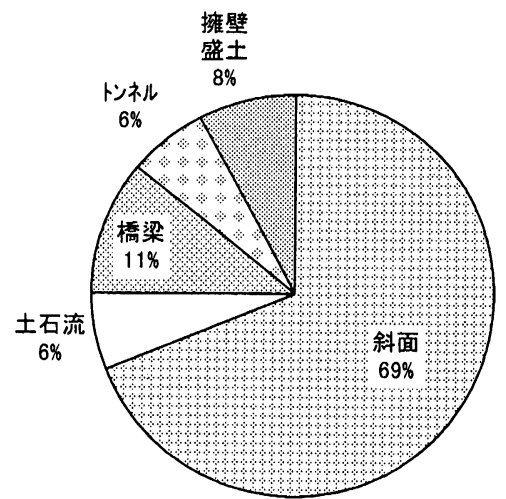

図一１道路防災ドクター診断箇所内訳（国土交通省資料）

Fig. 1 Items for inspection locations by road disaster doctors 


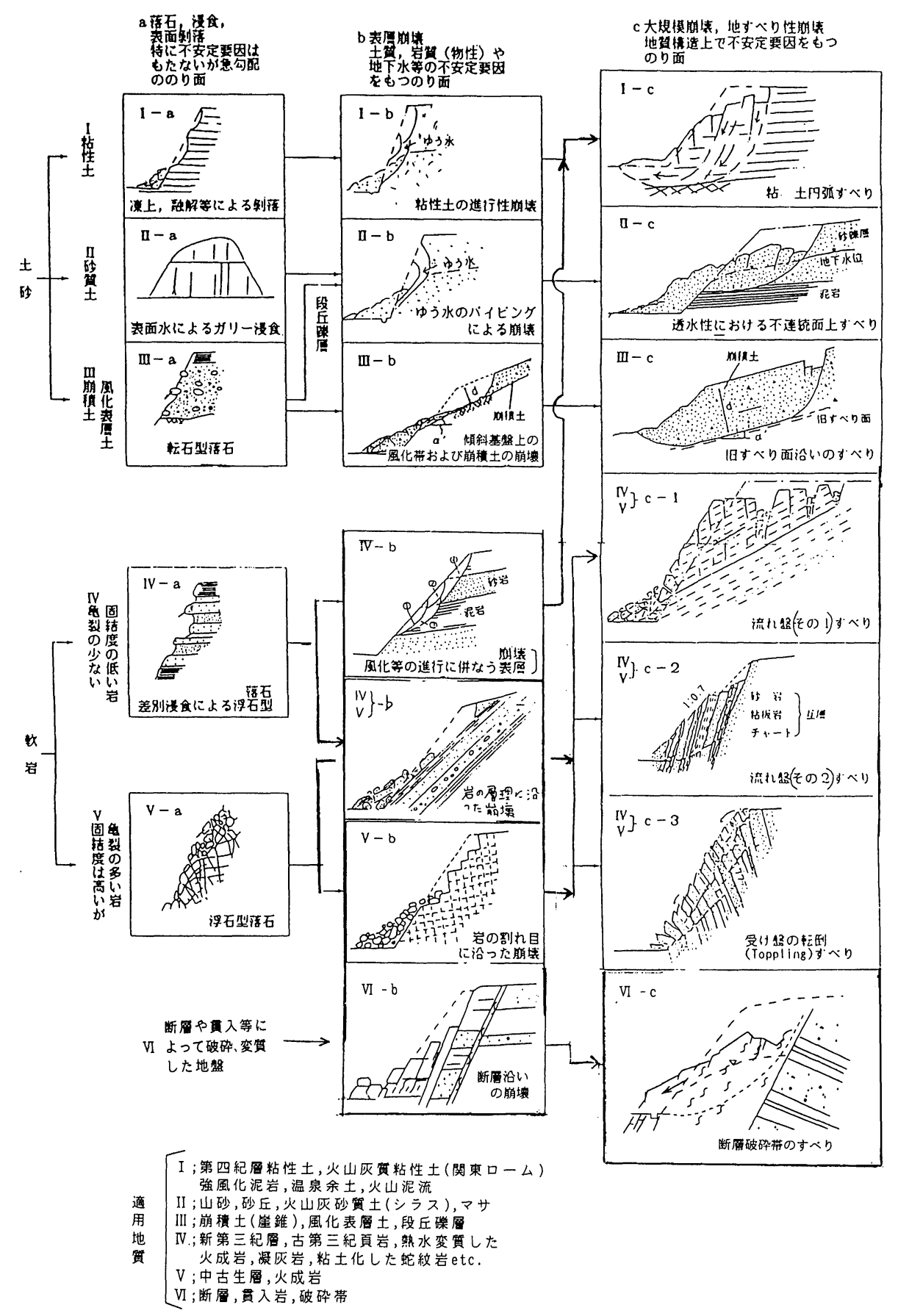

図一2 崩壊形態の分類（奥園原図）

Fig. 2 Classifications of failure forms

しい法面が続々と誕生するため，崩壊件数はむしろ増加 する傾向すらあるといえる。特に切土法面は，完成後の 時間経過とともに風化する宿命をもっているため, 崩壊 は施工時だけの問題ではない。これは，医学がどんなに 発達しても，老人が増えれば病院が㗇になることがない のと類似している。

ある国道で通行規制を伴う災害の発生実態を災害種別 にまとめた結果，切土法面の崩壊が $43 \%$, 盛土が $8 \%$, 泥土の流出が $22 \%$ という結果が出ており，斜面災害に起 因するものがいかに多いかがわかる。

図一 1 は九州地方整備局が平成13年度に実施した道路
防災ドクター（学識経験者）による道路の診断箇所数 （60ヶ所）の内訳である。この図でも法面や土石流等斜 面に関する診断が圧倒的に多いことがわかる。

切土法面は切土後の時間経過とともに風化等により地 山の強度が低下し，さらに建設時に設置された保護工も， いずれは老朽化していくし，排水機能もいつまでも効果 を発揮しているとは限らない。

以上のことから，斜面を健全に維持するためには，常 に点検管理し，補修を繰り返す必要がある。

また不幸にして災害を起こした場合，速やかに復旧し， 以後安全で安心できる法面へと改良してゆく必要がある。 


\section{2. 崩壊形態の定義と分類}

崩壊形態の分類には，規模による分類と性状による分 類がある。崩壊規模は大規模から小規模まであるが，こ の判別は受ける被害の“価值観”によって異なる。例え ば道路の場合, 建設中の崩壊は崩壊土量が数万 $\mathrm{m}^{3}$ 以上 を大規模崩壊というが, 完成して車が走り出した後は $1,000 \mathrm{~m}^{3}$ 超えると大崩壊と呼ぶことが多い。また小規 模で, 土砂の表層が剥離する程度のものを肌落ちと呼ん だり，岩石の場合は落石という。

中規模になり, 滑り面が急勾配で一度に落下する場合, 土砂がばらばらになって落ちてくるタイプをいわ沛る 「崩壊」または崩落と呼んでいる。大規模で滑り面の勾 配が緩く，土砂がゆっくりまとまって滑落するタイプは 地すべりと呼ばれている。大規模でも一度にばらばらに なって落下する場合は, 大規模崩壊という。“崩壊”は, 落石や地すべりと区分して中規模のものをいう場合と， 全体の現象を総称していう場合があり，ここでは後者を 使うことにする。

図一 2 は, 切土法面で発生する頻度の高い崩壊を, 夕 イプ（規模・性状）別に分類したものである。図の横方 向は規模別の分類で, 左より小 (a), 中 (b), 大 (c) の 順に並んでいる。さらに上下方向は土質・岩盤による分 類であり，上部から粘性土（Ｉ），砂質土（II)，礫質土ま たは崩積土・風化土 (III), 軟質岩 $(\mathrm{IV})$, 硬質岩 $(\mathrm{V})$, 破 砕带・変質帯 $(V I)$ の順に並んでいる。

図全体を見て次のような傾向がうかがえる。

(1) 小規模崩壊（aタイプ）は土質や岩質，つまり物性 によってその性状が変化する。しかし中（bタイプ） 〜大規模 (cタイプ) は，地質構造（不連続面）によっ てすべりの形状が決定される。

(2) 土砂, 特に粘性土 ( I ), 砂質土 (II), 破砕・変質带 (IV - cタイプ）のような, 土そのものの強度に支配さ れる破壊は, 円弧に近いすべりが起る。しかし，他の タイプは直線を含む破壊が多い。

平成元年以降 3 年間の, 法面災害について, 社全国防 災協会が全国の都道府県に対策事例調査を依頼したとこ ろ211件の回答があった。図ー3,4 はこの調査結果を図 -2 の分類で整理したものである2。図-3では意外に も V〜 I の順, つまり硬い物性の地山ほど崩壊が多いと いう結果となっている。図-4では, 中規模崩壊が 6 割 を占めて抢り，これは，最も人身事故を起こしやすい夕 イプである。

しかしこれは報告として挙げられたものの統計である。 図- 5 は沖縄自動車道が開通してからの法面崩壊全数 を対象とした規模の統計である (日本道路公団資料)。 やはり小規模崩壊が多いことがわかる。

\section{3. 切土法面の維持管理方針の概念}

法面を管理する者にとって最も避けるべきことは人身 事故であり, さらに道路や鉄道などの長期間の機能停止
による経済的損失である。これに対しては次のような対 策が必要となる。

a 崩壊しそうな法面を早期に発見して早期治療(対策) する。

b モニタリング（計測）や雨量規制により事前に通行 止めや避難をする。

c 災害復旧を効率よく処理する。

図 - 6 は横軸の法面崩壊確率に相当する超過確率（何 年に 1 度崩壊するか), 緃軸に 1 回当たりの人的損失額 または補強工（保護工等）に要する工費をとり，両者の 関係を示した概念図である。実線は一般的な法面の傾向

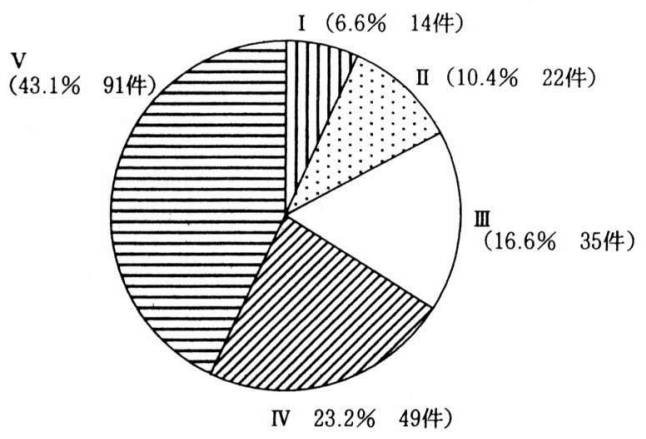

図-3 法面災害の地質分類 ${ }^{2)}$

Fig. 3 Geological classifications of cut slope failure

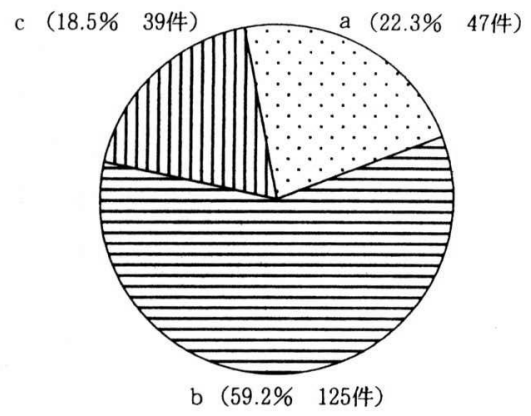

図一 4 法面災害の規模別分類 ${ }^{2)}$

Fig. 4 Scale based classifications of cut slope failure

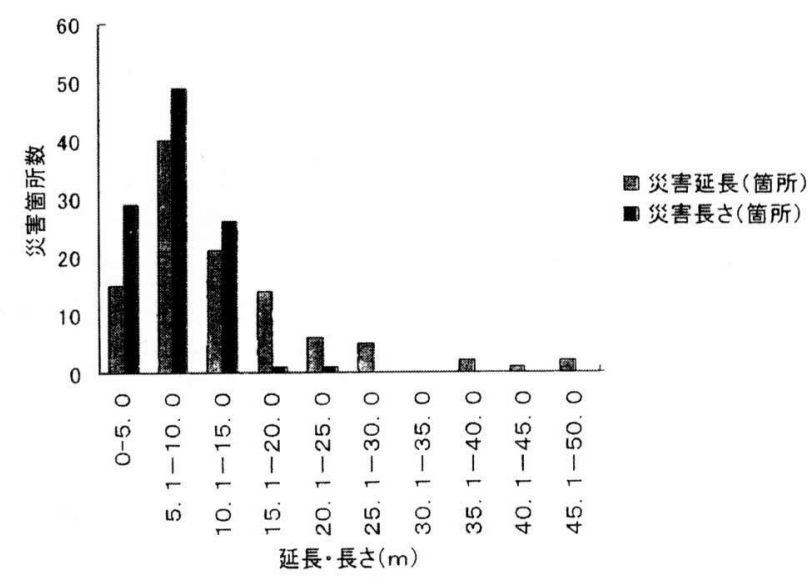

図一５災害規模一覧図（日本道路公団資料）

Fig. 5 Scale of failure 


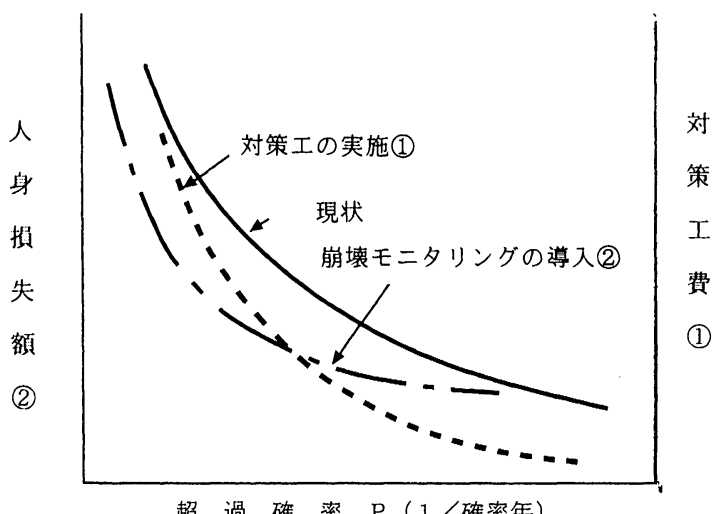

図一 6 崩壊確立と人身損失額・対策工費関係概念図

Fig. 6 Relationship of the failure probability with the expenses incurred due to death and the expenses involving countermeasures

を示すものである。すなわち図ー 5 でも示したように小 規模な崩壇ほど多数発生するが，その損失額は小さいた め図－6の不下側に位置する。一方，大規模な崩壊は滅 多に起らないが, 一旦発生すると, その損失額が大きく なるため図の左上側に位置することになる。

そこで事前に危険と思われる法面にお金をかけて補強 刘策工を実施すれば図の破線のように変化する。すなわ ち俩年起るような小規模な崩壊は大幅に低減できるが, 大きなものはそう簡単には低減できないことになり，ど こかで補強対策の限界線を引かねばならないことになる。 そうなると大規模崩壊が予想される異常降雨時や，計 测機器に異常値が测定された時には通行止めや住民避難 等の処置が必琶となってくる。

いわゆる逃げる技術によって人身損失額の低減を計る もので，同図の一点鎖線のように，滅多に発生しない大 崩壊対策としては，モニタリングや雨量規制によって人 身損失の軽減効果が上ることを示している。

\section{4. 不安定斜面の抽出}

法缅を管理するものにとって，最も知りたいのはその 法面がいつ崩壊するかである。崩壊を事前に予測するこ とができれば，事前に補強する対策が可能であろう。つ まり早期発見，早期治療である。

しかし，崩填子測技術は現在のところ未解明の分野で あり，近にこれが解明されれば，法面対策（調查，設計， 施工，維持管理）技術の大半が完成するといっても過言 ではない。

崩壊の予測は，これまでにも多くの研究がなされてい る。これらはいずれも次の要素のいずれかから判断され たものである。

a 法面構造的要素

地山の地形，岩質，土質，地質構造，地下水等の素 因に対してどのような法面構造（勾配，保護工）で設 計，施工されたかによる判定，つまり設計の見直しで ある。 b 法面変状的要素

建設後風化の進行，排水施設や保護工の機能の低下， 周辺環境の変化, 法面自体の変状 (クラック, 変位) 等による判定。

維持管理段階に入るとどちらかといえばbが主体と なる。

\section{1 目視・点検}

法面の安定性の検査はまず地表踏查・目視点検から始 まり，目視点検に終わるといってよい。

これは面的な情報，体感的情報を得るための必要条件 で，医学で言えば顔色や体温，血圧，聴打診等の検查に 相当する。

法面が崩壊する場合には, 地すべりのように前駆現象 （クラック，はらみ等の変形）が現れたり, 湧水が変化 したり, また排水設備の決壊, 保護工の疲労など目に見 えた変化が現れることもある。したがって，法面の点検 はこれらをいかに上手に把握するかにかかっている。

次に示す項目は筆者の拙い経験による不穴定な法面を 抽出するポイントをまとめたものである゙”。

なおこれらは経験工学的見知から現場の現象を捉えた ものである。あくまでも“一面の真理”であり，これに 一致しない例外があることは申すまでもないことである が念のためお断りしておきたい。

a 事前の基礎知識

(1) 建設中 (掘削直後) の露頭のスケッチや写真は, 点 検時の最大の情報。

(2) 建設中に無理をした法面は，必ず後でッケが廷って くる。

(3) 植生法面は, 構造物による保護法面よりも崩壊率が 高い。(前者が後者の 2 倍という統計もある)。変状 が識別しにくい植生法面こそ入念な検查を。

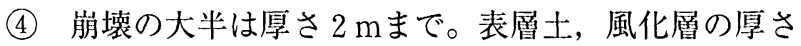
が安定性を支配する。

(5) 前科のある法面は要注意，その隣の法面も次の番。

(6) 小崩壊は集中豪雨時に (時間降雨量最大時), 大崩 壊は長雨の後に(連続降雨量数百ミリ)。

b 点検のポイント

(1) 法面点検のり肩歩け。

(2) 法面を登る時はミクロな調査を, 下る時にはマクロ な調査を。

(3) 点検記録はスケッチで（写真だけでは不十分）。

(4) 点検はなるべく同一人が，日々の変化を比較する。

(5) コンクリート吹付け裏の空洞，アンカーヘッドの腐 食等，目に見えない部分の点検は叮いて打診。

(6) 水拢き井戸（ウエル）の点検は流末（排水ボーリン グ）から。

c こういう箇所は要注意

(1) トンネル坑口上部の斜面は，緩んでいると思え。

(2) 冬でも緑（青々）している法面は水多し。

(3) 水抜き穴, 水抜きボーリング孔より多量の水が出る 
個所は，もともと危険個所。

(4) 天端から水が滴る擁壁の裏側は, 大きな水圧がか かっていると思え。

(5) 無いより悪い欠陷水路。

(6) 無いより悪い欠陥保護工。

(7) 小段に崩土，落石が堆積している個所は要注意。

(8) 落石防止ネットの老化, アンカーピンの緩み，ネッ 卜裏の土砂の溜まりは事故の元。

(9) 鉄筋扦入工法（ロックボルト）頭部のとび出し, 土 砂の中抜けは崩壊への序曲。

(10) 水の出口が無い凹地，原因不明の空洞は古い傷跡。

d 崩壊の前兆

(1) ガリー侵食（掘れ溝）はパイピングの前兆。パイピ ング（水の突出穴）は崩壊の前兆

(2) 法面の「はらみ」は水のせい。「はらみ」の上部は 引張り亀裂が。

(3) 法面横断方向（道路の場合は路線方向）のクラック は土圧がかかっている証拠。

(4) 孔内傾斜計に累積変位が現れた場合，警戒警報段階 と考えてよい。

(5) アンカーヘッド，ロックボルト頭部の相対的めり込 み現象は警戒警報。

（6) アンカー軸力（ロードセル等）が限界緊張力を超え たら緊急事態

法面完成後は保護工によって被覆されるため，地山の 内部の変化を直接検査することは目視点検では困難なこ とが多い。したがって点検は保護工の変状を観察するこ とが中心となる。

法面保護工の目的は，切土直後の地山条件をいかに長 期間保存するかにある。したがって保護工自体の変状は, その目的どおりの効果を発揮できないばかりでなく，保 護工部材自体が落下物（崩壊物質）と化してしまうこと がある。まさに“無いより悪い欠陥保護工”である。

上記の理由から保護工の変状の早期発見, 早期手直し は管理者としては重要な責務の一つである。

この場合, 地山の変状に起因しているか, 保護工単独 の欠陥による変状かを確認する必要がある゙”。

\section{2 計測によるモニタリング}

目視点検によって不安定な法面と判断されたら次に計 測によるモニタリングを行うことになる。これは面的に カバーすることはできないが，点や線状のいわば精密検 査といえる。

計測は(1)変位(2)圧力(3)振動に分けることができる。

\section{2.1 変位計による崩壊の予測}

計器による地山の変状を計測する場合, 最も多用され るのは伸縮計等による地表変位と挿入式孔内傾斜計等に よる地中変位計測である。

図 - 7 は地すべりの進行過程に伴い，孔内傾斜計に現 れる滑り面の形成状況を示した概念図である。左の列 (a) （a）斜面下部からの場合

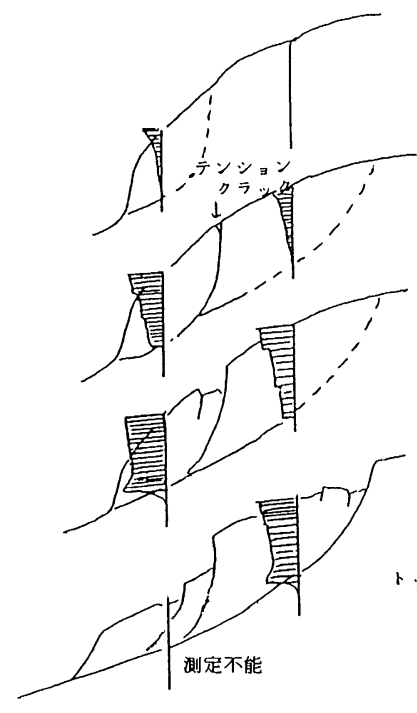

図一７ 孔内傾斜計による地中変位と滑り面の形成過程の概 念 (奥園原図)

Fig. 7 Concept of failure process and the deformation within the ground as obtained from inclinometer (a) From the bottom of the slope (b) From the top of the slope

は切土や末端の侵食などにより前方（下流側）から変状 が発達する場合である。右の列 (b) は降雨や融雪あるい は盛土等により後方（上流側）から押されて変状が発達 する場合である。いずれも第 2 段階（上から 2 段目）の ような剪断面（急変位部分）が確認されたら，警戒すべ き段階に入ったと考えてよい。

変位量の時間的変化（変位速度）から崩壊時間を推定 する技術は本学会でも数多く公表されており，筆者が改 めて紹介するまでもないが，過去の実績から変位が 3 次 クリープに入ったら，又は経験則から例えば変位速度が 時間 $0.2 \mathrm{~mm}$ に達したら厳重な警戒体制に入り，時間 4 $\mathrm{mm}$ に達したら通行止め，住民避難の意思決定をすべき であろう。

\subsection{2 圧力による判定}

地山の土圧や水圧を性格に測定することは，なかなか 困難である。しかし斜面は変形する以前から圧力が変化 する。したがって圧力の測定は変状を早期に発見出来る 可能性があるといえる。図－8は切土地区における土圧 をアンカーにかかる軸力（ロードセル）で測定した例で ある。ここでは軸力の増加に伴ってアンカーの増打ちを 行いその後の変状を抑止している。

地すべり地における地下水位（水圧）とすべりの移動 量との関係を示した例があるが4)，変位量が地下水位に 鋭敏に反応する場合（砂質系）と，それほど鋭敏ではな いもの（粘性系）とがある。

\subsection{3 振動による判定}

地山が崩壊する直前には振動が発生するといわれてい る。アコースティックエミッション (AE) と呼ばれる 


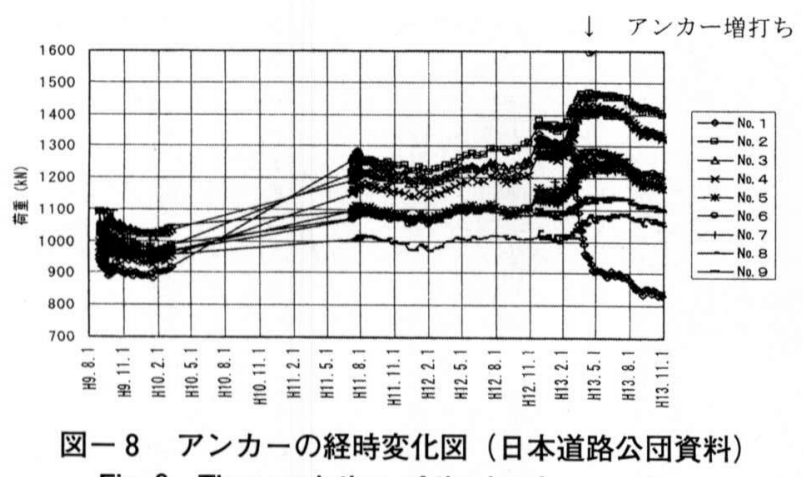

Fig. 8 Time variation of the load on anchors

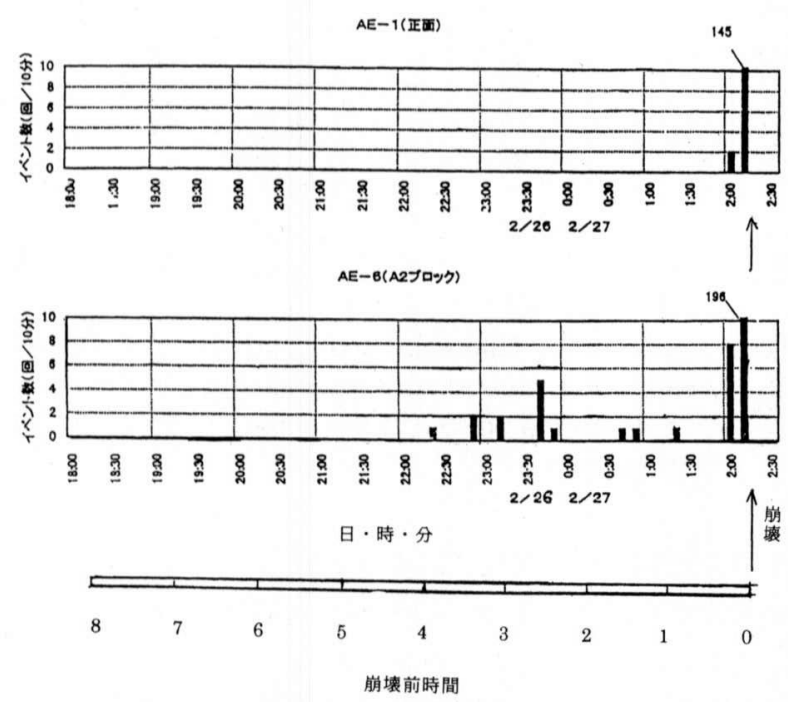

図-9 崩壊直前のAE発生数の推移（国土交通省資料）

Fig. 9 Time variation of the no. of Acoustic Emission(AE) just before the failure

振動から崩壊を予測する技術は，まだ未解明の分野と いってよい。ここでは現場での実測例を紹介するに留め ておきたい。

図－9 は岩盤の切土地山において，崩壊に至るまでの 間の振動回数を計測した例である。岩盤斜面の崩壊直前 に振動が起ることは十分考えられるが，そのデー夕をう まく採取できるか, デー夕を判断できるか, 結果を踏ま えて次の行動に移る時間があるか等活用面での問題点が 多い。

\section{5. 雨量規制値の設定}

図-10は高速道路の切土, 盛土法面が道路供用開始後 の経過年数とともに年間崩壊発生率がどのように変化し ていくかを示したものである。これは平成 5 年〜 10年の 5 年間における道路延長 $10 \mathrm{~km}$ 当たりの崩壊件数をその 間の年数で割ったものである。盛土は完成直後が最も発 生率が高く，その後急速に減少傾向がある。つまり「雨 降って地固まる」といえる。切土もその傾向があるが， 前述のとおり切土法面は時間経過とともに風化が進行す るため，減少傾向は鈍く，集中豪雨の年には増加する傾 向がある。それでも全般的には滅少傾向が伺えるのは崩

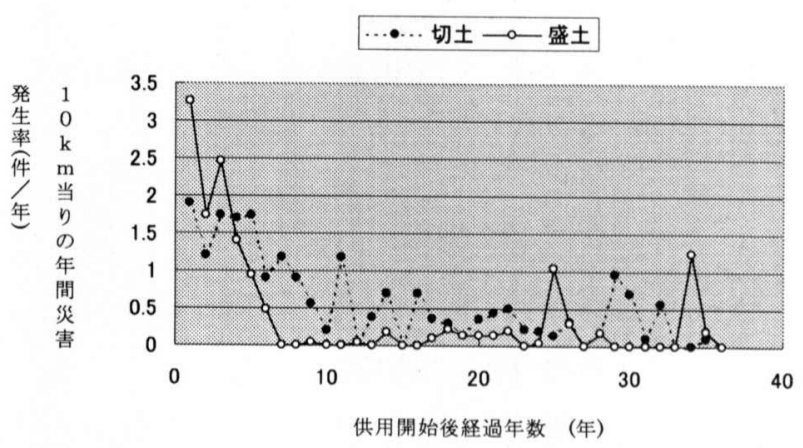

図ー10 高速道路における経過年数と災害発生率の実態（日 本道路公団資料・奥園加筆)

Fig. 10 Relationship between the rates of disaster incidence and elapsed time (in years) of highways

表一１規制基準見直し方法（日本道路公団資料）

Table 1 Correction method for regulation standard

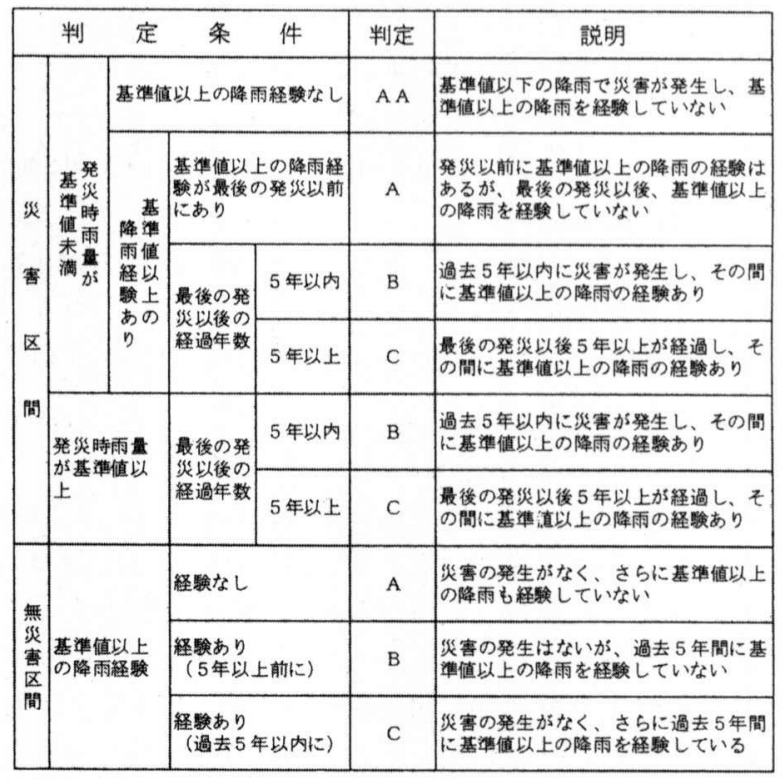

壊, 復旧, 改良の積み重ねによって長期間のうちに一種 の免疫性ができていったためと思われる。

したがって雨量規制值（通行止め基準雨量）も完成し てからの経過年数によって適宜見直してゆく必要がある。 表 - 1 は高速道路インターチェンジ間の規制值を見直す ときのルールをまとめた例である。

ここでは過去に災害を受けたか, それも 5 年以内か否 か, 次に今までの基準值以上の降雨を受けたか否か, そ れも 5 年以内か, 崩壊は基準值以上の雨で起ったか等で A， B，Cランクに区分される。AAやAと判断されたら その基準值以下でも崩壊が発生する恐れがあるから下方 へ修正する必要がある。 $\mathrm{B}$ 現行の基準值でよい。Cは 現行基準值では空振りが多く不経済であるから上方へ修 正してよい, という判断をすることになる。

図 - 11はある観測点における過去 20 年間の降雨履歴の うち，おおむね $50 \mathrm{~mm}$ 以上の連続降雨量に対しての時間 雨量と連続雨量相関図（スネーク曲線）である。過去の 崩壊例がプロットされているが必ずしも最高の雨量の時 


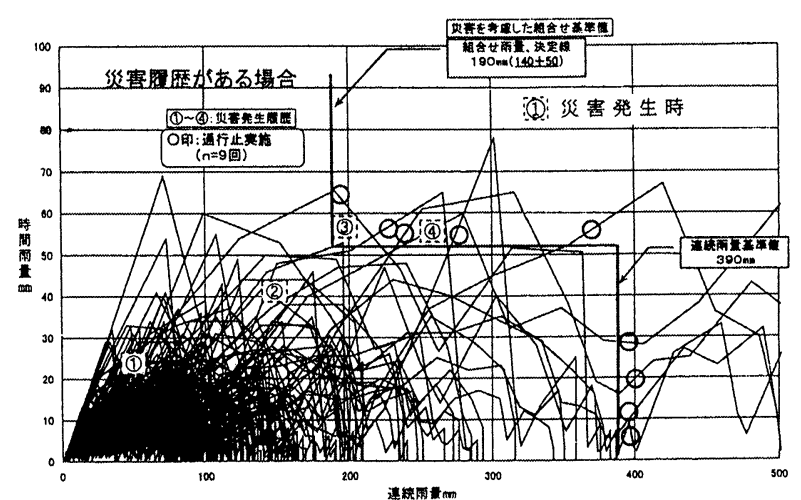

図-11 降雨履歴図による基準判定例(1)(日本道路公団資料)

Fig. 11 Judgment of standard by the history of low rainfall (Example 1)

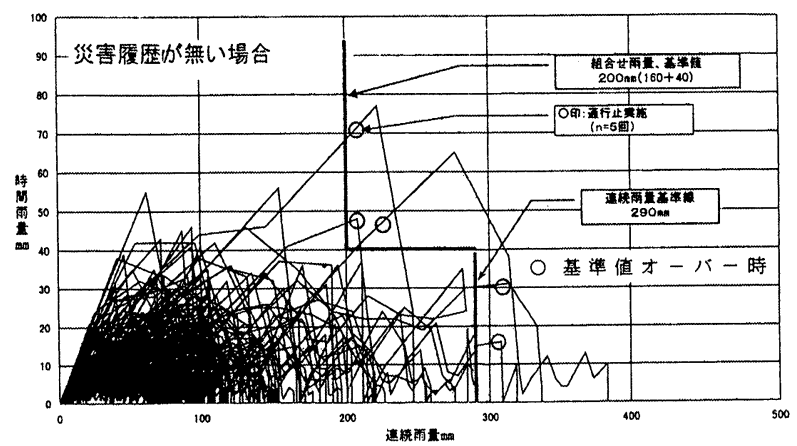

図一12 降雨履歴図による基準判定例(2)(日本道路公団資料)

Fig. 12 Judgment of standard by the history of low rainfall (Example 2)

点で崩壊していない。

少ない雨で崩壊したものはその原因を調べ，その後の 復旧改良状況を調べて例外扱いとすることがある。この 場合(1)と (2)は例外扱いとし, (3)と(4)は災害発生後それ以 上の雨も受けていないことから，このときの雨を参考と して雨量基準值を設定している。連続雨量 $390 \mathrm{~mm}$ はお おむね 5 年確率降雨量として設定している。

図－12は過去に崩壊を起こしていない地区の 20 年間の 降雨履歴の例である。ここでは連続雨量を 5 年確率雨量 とし，時間雨量と連続雨量の組み合わせは前者を 3 年確 率，後者を 2 年確率に設定している。つまり連続 $160 \mathrm{~mm}$ 降った後, 時間 $40 \mathrm{~mm}$ (連続雨量はこの時点で $200 \mathrm{~mm}$ ) 降ったら通行止めをするという基準值である。

\section{6. 異常時の点検管理}

計測機器が異常反応を示したり，異常降雨に見舞われ ても，道路や鉄道の通行止めや住民避難に踏み切る場合， やはり現場の点検により意思決定することになる。その 場合, 現場技術者, 巡回点検者の判断が大きなウェイト を占める。

集中豪雨の最中は，視界も悪く，しかも法面に立入る ことが困難なことが多い。この様な時, 道路の場合, 点 検者は路面から法面を観察するのが限度である。
表一2 道路点検者が体験した豪雨時切土法面崩壊直前の現 象 ${ }^{5)}$ (奥園加筆)

Table 2 State of cut slope just before the failure due to high rainfall as experienced by door inspectors

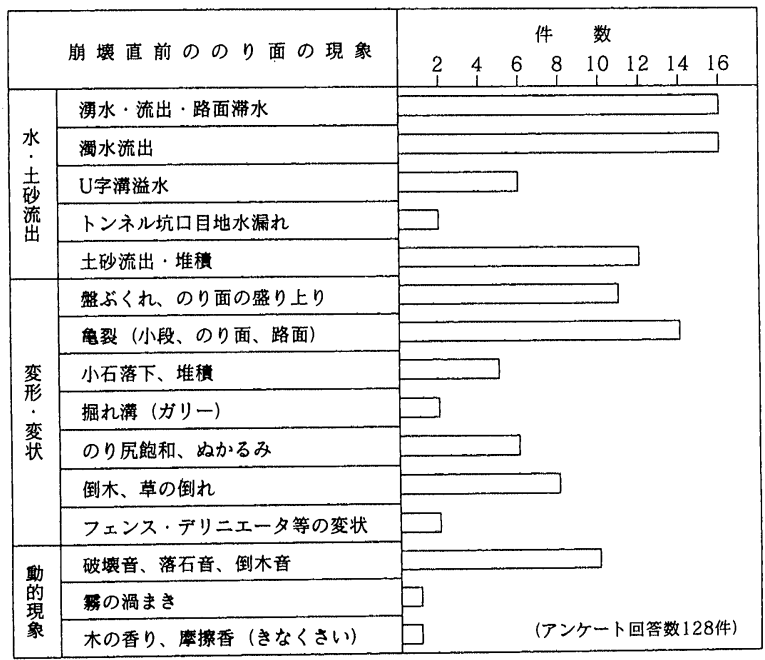

日本道路公団では，「異常気象時における道路点検に 関する検討会」を設け，豪雨時の点検手法等を検討した。 この中に，道路点検者がこれまでに体験した崩壊直前の 現象が集められている。表-2は，これらを集約したも のである5)。

同表から次のことがいえる

(1)わき水濁る，異常出水崩壊近し。

(2) 小石パラパラ崩壊近し。泥土の流れ出し崩壊近し。

(3) 法面の盛り上がりや亀裂の進行は崩壊がもう始まっ ている。

(4) 大崩壊の直前は音がする。

\section{あとがき}

雨が降り止み，地震が治まった時いつ規制解除を行う か, 実はこちらの方が難しい。大きな崩壊，例えば地す ベりほどタイムラグがあり，遅れて発生することがある。 解除の前に入念な点検が必要になってくる。このとき計 器の動き (モニタリング)が重要な意思決定の支援となる。

維持管理段階では法面の管理者は時間との勝負である。 減点主義で，何もないのが百点満点となる。点検に始ま り点検に終わる。正に名医より主治医 (ホームドクター) である。

\section{参考文献}

1）日本道路協会：のり面工斜面安定工指針，丸善1999.3.

2 ) 社全国防災協会：災害復旧のり面対策工法事例集（災害復旧 工法研究会編） 1994.3.

3 ）奥園誠之：斜面防災100のポイント，鹿島出版会 1986.11.

4) 渡正亮・小橋澄治：地すべり・斜面崩壊予知と対策, 山海堂 1987. 4 .

5 ）高速道路技術センター：異常気象時の道路点検に関する検討 会資料 1997.3 .

（原稿受付2004年10月12日，原稿受理2005年 1月17日） 